\title{
Decomposition of Mehran and Piesch inequality measures by factor components and their application to the distribu- tion of per capita household income in Brazil
}

\section{Rodolfo Hoffmann*}

\begin{abstract}
Inequality decomposition by factor components is extended to the Mehran and Piesch indices, comparing them with the decomposition of the Gini index, the squared coefficient of variation and the Theil's $T$ coefficient. The decomposition procedure is applied to the distribution of per capita household income in Brazil in 1999, considering six components: earnings of civil servants and military personnel, earnings of other employees, earnings of self-employed workers, earnings of employers, pensions and, finally, all other incomes. One of the results is that for all the five measures used, the concentration ratio of pensions is higher than the overall index of inequality, indicating that this component is contributing to the increase in income inequality.
\end{abstract}

\section{Resumo}

A decomposição da desigualdade conforme parcelas do rendimento é estendida aos índices de Mehran e Piesch, comparando-a com a decomposição do índice de Gini, do quadrado do coeficiente de variação e do $\mathrm{T}$ de Theil. O procedimento é aplicado à distribuição do rendimento domiciliar per capita no Brasil em 1999, dividindo-o em 6 parcelas: rendimento do trabalho de militares e funcionários públicos, rendimento do trabalho de empregados, rendimento do trabalho dos conta-própria, rendimento do trabalho de empregadores, rendimento de aposentadorias e pensões e uma parcela com os demais rendimentos. Um dos resultados é que para todos os 5 índices utilizados a "razão de concentração" de aposentadorias e pensões é um pouco maior do que a medida geral de desigualdade, indicando que esses rendimentos estão contribuindo para aumentar a desigualdade .

Key Words: inequality, income distribution, decomposition by factor components .

JEL Code: C10, D31, D33 .

${ }^{*}$ Professor, School of Economics, Universidade de Campinas, Brazil, with research support from CNPq. The author gratefully acknowledges the help received from Helga Hoffmann and the valuable comments from an anonymous referee.

$\overline{\text { Brazilian Review of Econometrics Rio de Janeiro v.24, } \mathrm{n}^{\mathrm{O}} 1, \text { pp.149-171 May } 2004}$ 
Decomposition of Mehran and Piesch inequality measures by factor components

\section{Introduction.}

One may be interested in decomposing measures of income inequality by population subgroups such as those defined by sex, regions of a country, age or schooling levels. This is, indeed, the most common type of inequality decomposition in the literature about income distribution, with Theil's $\mathrm{T}$ and $\mathrm{L}$ inequality measures being the preferred ones for this objective. In this case, the Gini index is not convenient because its decomposition produces not only terms related to between- and within-group inequality, but also a third component related to the overlapping of the income distributions of the population subgroups.

One different type of decomposition must be used when one wishes to assess the contribution of components of individual income, such as labor income or pensions, to overall inequality. In this case, the Gini index is the most commonly used inequality measure. The decomposition of the Gini index by factor components was analyzed by Pyatt, Chen \& Fey (1980), showing its relations with concentration curves. The squared coefficient of variation is also frequently used for this purpose. Shorrocks ( 1983) also uses Theil's T decomposition.

Shorrocks (1982) makes a severe critique of the possibility of measuring the contribution of factor components to overall inequality. The paper indicates that the best measure for this purpose is the squared coefficient of variation. But this inequality measure is very sensitive to changes in the upper tail of the income distribution. If we want to use a caricature, we may say that the squared coefficient of variation is the appropriate measure of inequality in a study of the demand for yachts, which would be affected by income transfers from the rich to the extremely rich. Therefore, it is very inconvenient to limit the inequality decomposition by factor components to the squared coefficient of variation. 
In this paper we show that the decomposition of the Gini index by factor components can be readily extended to the Mehran and Piesch indices. The decomposition of these 3 measures is then compared to the decomposition of Theil's $\mathrm{T}$ index and the squared coefficient of variation. Data about the per capita household income in Brazil are used to illustrate the decomposition of all five inequality measures, showing that the results are coherent and informative

\section{Inequality measures and their decomposition.}

Consider that $y_{i}$ is the income of a person in a population with $n$ people and assume that income has $k$ components:

$$
y_{i}=\sum_{h=1}^{k} y_{h i}, \quad \text { where } \quad y_{h i} \geq 0
$$

If the average of the $n$ values of $y_{i}$ is $\mu$, and the average of the $n$ values of the $h^{\text {th }}$ component is $\mu_{h}$, its share in total income is

$$
\varphi_{h}=\frac{\mu_{h}}{\mu}
$$

Let us assume that incomes $y_{i}$ are ordered in such a way that $y_{i} \leq y_{2} \leq \ldots \leq y_{n}$. Then $i$ is the rank of income $y_{i}$. The coordinates of the points in the Lorenz curve are

$$
p_{i}=\frac{i}{n}
$$

and

$$
\Phi_{i}=\frac{1}{n \mu} \sum_{j=1}^{i} y_{j}
$$


Decomposition of Mehran and Piesch inequality measures by factor components

Defined below are three measures of inequality directly associated with the area between the Lorenz curve and the line of perfect equality $(\Phi=p)$ : the Gini index $(G)$, the Mehran index $(M)$ and the Piesch index $(P)$ :

$$
\begin{aligned}
G & =\frac{2}{n} \sum_{i=1}^{n-1}\left(p_{i}-\Phi_{i}\right), \quad \text { with } \quad 0 \leq G \leq 1-\frac{1}{n} \\
M & =\frac{6}{n} \sum_{i=1}^{n-1}\left(1-p_{i}\right)\left(p_{i}-\Phi_{i}\right), \quad \text { with } \quad 0 \leq M \leq 1-\frac{1}{n^{2}} \\
P & =\frac{3}{n} \sum_{i=1}^{n-1} p_{i}\left(p_{i}-\Phi_{i}\right), \quad \text { with } \quad 0 \leq P \leq\left(1-\frac{1}{n} \quad \frac{1}{2 n}\right)(7)
\end{aligned}
$$

Note that in the Mehran index the difference between the ordinate of the line of perfect equality and the ordinate of the Lorenz curve is weighted by $1-p_{i}$, making this index relatively more sensitive to changes in the lower end of the distribution, when compared to the Gini index. In the Piesch index the weighting factor is $p_{i}$, making it relatively more sensitive to changes in the upper end of the distribution. The Gini and Mehran indices are particular cases of the extended Gini coefficient introduced by Yitzhaki (1983) with $\nu=2$ and $\nu=3$, respectively. Nygard and Sandstrom (1981) mention two more measures of the same nature: the measures proposed by Bonferroni and De Vergottini. We are not going to deal with these two measures because their value changes if we replicate the distribution an integer number of times, that is, if we duplicate, triplicate, etc. the distribution.

But we will analyze here two additional measures of inequality: Theil's T coefficient $(T)$ and the squared coefficient of variation $(Q)$ : 


$$
\begin{aligned}
& T=\frac{1}{n} \sum_{i=1}^{n} \frac{y_{i}}{\mu} \ln \frac{y_{i}}{\mu} \\
& Q=\frac{1}{\mu^{2}} V\left(y_{i}\right)=\frac{1}{n \mu^{2}} \sum_{i=1}^{n} y_{i}^{2}-1
\end{aligned}
$$

Pyatt, Chen and Fei (1980) begin their analysis of inequality decomposition according to components of income by defining the concentration curves. Note that we will maintain the $n$ values of each component $y_{k i}$ ordered according to the value of $y_{i}$. In a way analogous to (4) we calculate

$$
\Phi_{h i}=\frac{1}{n \mu_{h}} \sum_{j=1}^{i} y_{h j}
$$

The points of coordinates $p_{i}, \Phi_{h i}$ define the concentration curve of the $h^{\text {th }}$ component. It can be observed that the ordinate of the Lorenz curve is a weighted average of the ordinates of the concentration curves of the $k$ components:

$$
\Phi_{i}=\sum_{h=1}^{k} \varphi_{h} \Phi_{h i}
$$

Pyatt, Chen and Fei define the concentration ratio ${ }^{1}$ of one component as twice the area between the line of perfect equality and the concentration curve, considering the sign of $p_{i}-\Phi_{h i}$, and demonstrate that this ratio is a function of the covariance between $y_{h i}$ and the order position $i$ :

\footnotetext{
${ }^{1}$ Called "concentration coefficient" in Lambert (1989, p. 50) and "concentration index" in Kakwani (1980, p. 173).
} 
Decomposition of Mehran and Piesch inequality measures by factor components

$$
C_{G h}=\frac{2}{n \mu_{h}} \operatorname{cov}\left(y_{h i}, i\right)
$$

It can be verified that the Gini index of the distribution is the "concentration ratio" of income $y_{i}$

$$
G=\frac{2}{n \mu} \operatorname{cov}\left(y_{i}, i\right)
$$

We intentionally included a $G$ subscript in the symbol of the concentration ratio in (12), since we will later define "concentration ratios" associated with other inequality measures. The concentration ratios may be obtained also through an expression analogous to (5):

$$
C_{G h}=\frac{2}{n} \sum_{i=1}^{n-1}\left(p_{i}-\Phi_{h i}\right)
$$

With $y_{h i} \geq 0$, we have

$$
-1+\frac{1}{n} \leq C_{G h} \leq 1-\frac{1}{n}
$$

It can be demonstrated that

$$
G=\sum_{h=1}^{k} \varphi_{h} C_{G h}
$$

This decomposition of the Gini index is carefully analyzed by Pyatt, Chen and Fei (1980).

Note, in expression (16), that in case all concentration ratios $C_{G h}$ had the same value, this would be, also, the value of $G$. Thus, 
it is reasonable to conclude that a component $y_{h i}$ contributes to the increase in inequality (as measured by the Gini index) when $C_{G h}>G$.

Using the weighting factors $\left(1-p_{i}\right)$ of the Mehran index we can define "concentration ratios" corresponding to that inequality measure:

$$
C_{M h}=\frac{6}{n} \sum_{i=1}^{n-1}\left(1-p_{i}\right)\left(p_{i}-\Phi_{h i}\right)
$$

Analogously, the "concentration ratios" associated with the Piesch index are given by

$$
C_{P h}=\frac{3}{n} \sum_{i=1}^{n-1} p_{i}\left(p_{i}-\Phi_{h i}\right)
$$

It is easy to verify that

$$
M=\sum_{h=1}^{k} \varphi_{h} C_{M h}
$$

and

$$
P=\sum_{h=1}^{k} \varphi_{h} C_{P h}
$$

We have, thus, a decomposition of the Mehran index and the Piesch index analogous to the decomposition of the Gini index.

For the squared coefficient of variation, we define 
Decomposition of Mehran and Piesch inequality measures by factor components

$$
C_{Q h}=\frac{1}{\mu \mu_{h}} \operatorname{cov}\left(y_{i}, y_{h i}\right)=\frac{1}{n \mu \mu_{h}} \sum y_{i} y_{h i}-1
$$

It can be verified that

$$
Q=\sum_{h=1}^{k} \varphi_{h} C_{Q h}
$$

This decomposition of $Q$ corresponds to the "natural" decomposition of the variance analyzed by Shorrocks (1982). It is better to consider the decomposition of the squared coefficient of variation because variance is a measure of dispersion and strictly it is not an inequality measure.

The "natural" decomposition of Theil's T index is

$$
T=\sum_{h=1}^{k} \varphi_{h} C_{T h}
$$

where

$$
C_{T h}=\frac{1}{n} \sum_{i=1}^{n} \frac{y_{h i}}{\mu_{h}} \ln \frac{y_{i}}{\mu}
$$

Beginning with a set of assumptions, Shorrocks has tried to deduce a decomposition rule of inequality measures according to the components of income. He has shown that the definition of the decomposition rule is to a large extent arbitrary. Any index may be decomposed in such a way that the contribution of a given component to inequality is equal to the contribution in the natural decomposition of any other index. He then adds the assumption that, in case 
income consists of two components only, and one of the components is a permutation of the other one, the contribution of each component to inequality will be the same. He shows that only decompositions that bring the same result as the natural decomposition of the squared coefficient of variation are coherent with such an assumption (assumption number 6 in Shorrocks).

It is not reasonable, however, to limit this type of decomposition to the results obtained through the decomposition of $Q$. Moreover, since the coefficient of variation is very sensitive to changes in the upper end of the distribution (see Hoffmann, 1998, chapter 7), it is not even reasonable to give preference to the decomposition of $Q$, instead of the results obtained through the decomposition of the Gini index. This means that we do not accept assumption 6, presented by Shorrocks (1982), as necessary.

A numerical example will help understand the problem. Table 1 presents numbers for the two components and the total income of a fictitious population of only 5 people. Note that the values of $y_{2}$ are a permutation of the values of $y_{1}$.

Table 1. Values of the components $\left(y_{1}\right.$ and $\left.y_{2}\right)$ and of the income $\left(y=y_{1}+y_{2}\right)$ of 5 people.

\begin{tabular}{rcc}
\hline$y_{1}$ & $y_{2}$ & $y$ \\
\hline 1 & 1 & 2 \\
2 & 2 & 4 \\
6 & 1 & 7 \\
1 & 30 & 31 \\
30 & 6 & 36 \\
\hline
\end{tabular}

Table 2 shows, for this fictitious distribution, the value of the following indices: Gini $(G)$, Mehran $(M)$, Piesch $(P)$, Theil's T $(T)$ and the squared coefficient of variation $(Q)$. It also shows the corresponding "concentration ratios" for each component. 
Decomposition of Mehran and Piesch inequality measures by factor components

Table 2. Inequality decomposition for the numbers given in Table 1.

\begin{tabular}{lcclc}
\hline \hline Statistic & $y_{1}$ & $y_{2}$ & $y$ & $\begin{array}{c}\% \text { related to } \\
y_{1}{ }^{(1)}\end{array}$ \\
\hline$\mu_{h}$ and $\mu$ & 8 & 8 & 16 & - \\
$\varphi_{h}$ & 0.5 & 0.5 & 1.0 & - \\
$C_{G h}$ and $G$ & 0.57 & 0.38 & 0.475 & $60 \%$ \\
$C_{M h}$ and $M$ & 0.714 & 0.630 & 0.672 & $53.1 \%$ \\
$C_{P h}$ and $P$ & 0.498 & 0.255 & 0.3765 & $66.1 \%$ \\
$C_{Q h}$ and $Q$ & 0.8172 & 0.8172 & 0.8172 & $50 \%$ \\
$C_{T h}$ and $T$ & 0.3794 & 0.4757 & 0.4276 & $44,4 \%$ \\
\hline
\end{tabular}

(1) Percentage contribution of the first component to inequality.

As demonstrated by Shorrocks (1982), for the squared coefficient of variation each component contributes exactly $50 \%$ to inequality. The first component takes its highest value for the richest person $(y=36)$ and that is essentially the reason why the respective concentration curve defines a larger surface below the line of perfect inequality, thus making its contribution to the Gini index equal to $60 \%$. For the Piesch index, where the weighting is higher in the upper end of the distribution, the contribution of the first component to inequality reaches $66.1 \%$.

To stress how the behavior of Theil's $\mathrm{T}$ is different, let us take the case of an income that has two components, the first of which has the same value for all the persons in the population. For indices $G, M$, $P$ and $Q$, the "concentration ratio" of this first component is zero, which means that this component does not contribute to inequality. However, when we decompose Theil's $\mathrm{T}$ we get, in this example, $C_{T 1}$ equal to the negative of Theil's $L$ of the distribution of $y_{2}$, that is, the contribution of this component is negative, whenever there is some variation in the value of the other component. The contribution of this other component will then be higher than $100 \%$. Shorrocks 
suggests that such a result correctly reflects the "equalizing" effect of the constant component. But for someone used to the decomposition of the Gini index such a result seems strange, because $C_{G h}$ becomes negative only if the respective concentration curve is located above the line of perfect equality, that is, if the values of the component are larger for the relatively poor.

Let us examine the fictitious distribution presented in Table 3.

Table 3. Values of the components $\left(y_{1}\right.$ and $\left.y_{2}\right)$ and of the income $\left(y=y_{1}+y_{2}\right)$ of 5 persons.

\begin{tabular}{ccc}
\hline$y_{1}$ & $y_{2}$ & $y$ \\
\hline 4 & 1 & 5 \\
5 & 1 & 6 \\
7 & 2 & 9 \\
11 & 6 & 17 \\
13 & 30 & 43 \\
\hline
\end{tabular}

In this fictitious example each component represents half of the total income. Both components grow monotonically, although it is obvious that there is more inequality in the second component. The contribution of the first component to inequality is $21.9 \%$ with the squared coefficient of variation, $27.6 \%$ with the Gini index, $30.5 \%$ with the Mehran index, $25.3 \%$ with the Piesch index and it is virtually null $(-0.25 \%)$ in the decomposition of Theil's T.

The fact that the concentration ratios in the Gini, Mehran and Piesch indices are directly related to the position of the concentration curves certainly simplifies the interpretation of the decomposition of these indices. It would be advisable to jointly use those three indices, given the different weightings along the distribution. But one should not dismiss the decomposition of $Q$ or $T$. And it should not be forgotten that with the decomposition of $T$ it is easier that 
Decomposition of Mehran and Piesch inequality measures by factor components the contribution of one component happens to be negative (thus increasing the contribution of the remaining components).

\section{Decomposition of inequality in Brazil in 1999.}

Next, we examine the contribution of several components of household income to inequality in the distribution of the per capita household income in Brazil, according to data from the Brazilian National Sample Survey of Households of 1999 (which will be referred to as PNAD-Pesquisa Nacional por Amostra de Domicilios).

The Brazilian Institute of Geography and Statistics "considered as monthly household income the sum of monthly incomes of those living in the same household, excluding paid guests, domestic servants and family members of domestic servants" (IBGE, 2000). The per capita household income was obtained by dividing the monthly household income by the number of persons in the household (excluding paid guests, domestic servants and their family members).

We analyzed only private permanent households who declared a household income, namely, a sample of 91,574 households, corresponding to $41,861,683$ households in the population, with 155.6 million people in the categories included.

One should keep in mind the limitations of the data on income obtained through the PNAD questionnaire. The total declared income considerably underestimates the national income. The main reason for this is the tendency in households to avoid declaring all their income, resulting in understatement, in particular amongst the highest incomes. But one should remember that the PNAD does not capture the value of production for self-consumption. It is very difficult to establish with precision what the incomes of rural producers are, and income from capital is particularly understated.

It should be noted, as well, that "income from work", for IBGE, 
is the income gained in any activity undertaken (and declared) by the individual, and is not limited to wages. Income from work includes not only the income of employees, but also the income of own-account (self-employed) workers and employers.

Finally, we should recall that the PNAD does not collect data in the rural area of the former North region (states of Rondonia, Acre, Amazonas, Roraima, Pará and Amapá).

In an analysis of the decomposition of income inequality by factor components, the type of decomposition of individual incomes must be chosen according to the objectives of the research. In a previous paper (Hoffmann, 2003) whose main objective was to show the participation of pensions in the decomposition of the Gini index in Brazil, the following income components were considered: earnings from main occupation, earnings from other occupations, pensions, donations, rents and a residual component including interest, dividends and other incomes. Here we want to verify whether the conclusion of that paper about the contribution of pensions to income inequality in Brazil is robust in relation to the choice of the inequality measure. Therefore, pensions are maintained as a component. The "earnings" part of income will be divided into four parts, according to the type of the person's main occupation: military and civil servants, other employees, self-employed and employers. Thus, household income will be divided into six components:

1- Earnings of civil servants and military personnel (CSM)

2- Earnings of employees, excluding civil servants and military personnel (EMP)

3- Earnings of self-employed workers (SLF)

4- Earnings of employers (YER)

5- Income from retirement pensions and other pensions (disability, widowers, etc.) (PEN) 
Decomposition of Mehran and Piesch inequality measures by factor components

6- Incomes from rents, donations, interests, dividends, etc ${ }^{2}$. (RDI)

Tables 4 and 5 show the main results for Brazil as a whole. Income from work of employees ${ }^{3}$ represents $38.6 \%$ of the total income. The next main components are income from own-account activity (self-employed) and from pensions, each with an $18 \%$ share. The earnings of employers represent $12 \%$ of the total income, and the wages of civil servants and the military constitute $10.2 \%$ of the total income $(0.7 \%$ for the military and $9.5 \%$ for civil servants). Again, a reminder: these percentages are affected by differences in the degree in which those types of incomes are understated.

Table 4. Brazil, 1999. Division of the per capita household income into 6 components and their average value $(\mu)$, share in total income $(\varphi)$ and decomposition of the squared coefficient of variation $(Q)$ and of Theil's T $(T)$.

\begin{tabular}{lrccccc}
\hline \hline Component & $\mu(\mathrm{R} \$)$ & $\varphi$ & $C_{Q}$ & \multicolumn{1}{c}{$\%$} & \multicolumn{1}{c}{$C_{T}$} & \multicolumn{1}{c}{$\%$} \\
\hline CSM & 25.9 & 0.102 & 3.298 & 10.5 & 0.990 & 14.3 \\
EMP & 98.3 & 0.386 & 1.939 & 23.5 & 0.412 & 22.5 \\
SLF & 45.2 & 0.177 & 2.112 & 11.8 & 0.446 & 11.2 \\
YER & 30.6 & 0.120 & 7.669 & 28.9 & 1.598 & 27.2 \\
PEN & 45.4 & 0.178 & 3.254 & 18.2 & 0.742 & 18.7 \\
RDI & 9.5 & 0.037 & 6.132 & 7.2 & 1.156 & 6.1 \\
\hline Total & 254.9 & 1.000 & 3.186 & 100.0 & 0.706 & 100.0 \\
\hline
\end{tabular}

\footnotetext{
${ }^{2}$ Includes some residual income from work that could not be classified into the first 4 components.

${ }^{3}$ In this text "employees" mean always "employees who are neither civil servants nor military". When including civil servants and military I will use the expression "all employees".
} 
Table 5. Brazil, 1999. Division of the per capita household income into 6 components: decomposition of the Gini, Mehran and Piesch indices.

\begin{tabular}{lcrrrrr}
\hline \hline Component & $C_{G}$ & \multicolumn{1}{c}{$\%$} & \multicolumn{1}{c}{$C_{M}$} & \multicolumn{1}{c}{$\%$} & \multicolumn{1}{c}{$C_{P}$} & $\%$ \\
\hline CSM & 0.733 & 12.6 & 0.872 & 12.2 & 0.664 & 12.8 \\
EMP & 0.498 & 32.4 & 0.646 & 34.4 & 0.424 & 31.1 \\
SLF & 0.505 & 15.1 & 0.635 & 15.6 & 0.440 & 14.8 \\
YER & 0.857 & 17.4 & 0.945 & 15.7 & 0.812 & 18.5 \\
PEN & 0.603 & 18.1 & 0.736 & 18.1 & 0.536 & 18.2 \\
RDI & 0.691 & 4.3 & 0.782 & 4.0 & 0.646 & 4.6 \\
\hline Total & 0.592 & 100.0 & 0.724 & 100.0 & 0.526 & 100.0 \\
\hline
\end{tabular}

All five decompositions indicate that only components EMP (employees) and SLF (self-employed) contribute to a reduction in overall inequality, as their "concentration ratios" are lower than the overall inequality measure, and thus their percentage contribution to total inequality is lower than their share in total income.

The highest "concentration ratio" is always associated with the income of employers. As expected, the corresponding concentration curve remains low for relatively poor households and increases rapidly only when we reach the richest $10 \%$. Nevertheless, for indices $G, M$ and $P$ the largest contribution to total inequality comes from the earnings of employees, because this component represents a much higher share of total income.

For indices $G, M$ and $P$, the second place in a decreasing ranking of the concentration ratios is occupied by the income of civil servants and military. This type of income is positive (non-null) in only $10.3 \%$ of the households and the Gini index of the distribution of these positive values is 0.565 . The fact that the corresponding concentration ratio is far higher $\left(C_{G}=0.733\right)$ reflects the relatively privileged position in the distribution of per capita family income 
Decomposition of Mehran and Piesch inequality measures by factor components

enjoyed by many of the Brazilian civil servants and military. It can be verified that the households with a monthly per capita income above $\mathrm{R} \$ 300$ (in 1999) represent $26.1 \%$ of all households, are home to $21.3 \%$ of all persons, receive $65.0 \%$ of all income, $77.0 \%$ of all military earnings and $79.1 \%$ of all civil servants' earnings.

Aggregating the two employee categories, their earnings share in total income is 0.488 and the corresponding concentration ratio for the Gini index can be calculated as a weighted average:

$$
C_{G}=\frac{0.733 \times 0.102+0.498 \times 0.386}{0.102+0.386}=0.547
$$

In a similar way we can compute the concentration ratios for all employees earnings for the other measures of inequality: $C_{Q}=2.223$, $C_{T}=0.533, C_{M}=0.693$ and $C_{P}=0.474$. Notice that these concentration ratios are substantially lower than both the corresponding index of inequality and the concentration ratio for pensions.

When we aggregate the earnings of all employees and of selfemployed workers, their share in total income is $66.5 \%$ and their contribution to total inequality is around $60 \%$ for the Gini, Mehran and Piesch indices.

By aggregating all earnings (including employers' earnings), the share in total income reaches $78.5 \%$ and the contribution to total inequality ranges from $75 \%$ to $78 \%$. It must be remembered that this contribution is overestimated due to the stronger understatement of income from rents, interest and dividends.

In all five decompositions the "concentration ratio" of pensions is higher than the overall inequality measure, indicating that these incomes are contributing to the increase in inequality ${ }^{4}$. The share of

\footnotetext{
${ }^{4}$ Shorrocks (1983) presents a decomposition of family income inequality using data from the Michigan Survey of Income Dynamics for the 1968-1977 period. The results are not directly
} 
the contribution of pensions to total inequality is always slightly over $18 \%$; it is the second largest contribution amongst the 6 components in the case of indices $G$ and $M$, and is the third largest contribution in indices $Q, T$ and $P$.

The concentration ratio of CSM is always higher than the concentration ratio for pensions. However, as shown before, when we aggregate the earnings of all employees, the corresponding concentration ratio is always lower than the concentration ratio for pensions.

In our "residual" component RDI, the PNAD data allow us to distinguish income from rents (with $\varphi_{h}=0.022$ and $C_{G h}=0.803$ ), donations from other households $\left(\varphi_{h}=0.007\right.$ and $\left.C_{G h}=0.354\right)$ and interest, dividends, etc. $\left(\varphi_{h}=0.008\right.$ and $\left.C_{G h}=0.695\right)$. The latter component includes some government income transfers to the poor that causes it to be less concentrated in rich households. As expected, rents are highly concentrated and donations from other households have a much lower (but still positive) concentration ratio.

Tables 6 and 7 show the decomposition of inequality in the Northeast region of Brazil, using the same 6 components of per capita household income. The two lowest "concentration ratios" are always associated with the earnings of employees (EMP) and self-employed workers (SLF). Nevertheless, due to the fact that component EMP (wages of employees) represents $31.6 \%$ of the total income, its percentage contribution to total inequality is the highest amongst the 6 components in the case of indices $G, M$ and $P$.

Pensions of retirees, disabled, etc. (PEN) represent $21.4 \%$ of the total income in the Northeast. The contribution of this component to total inequality is always equal to or higher than its share in

\footnotetext{
comparable with those presented in this paper, but it may be relevant to note that he obtained a negative concentration ratio for pensions in the decomposition of the Gini index, Theil's $\mathrm{T}$ and the squared coefficient of variation.
} 
Decomposition of Mehran and Piesch inequality measures by factor components

total income. For all the inequality measures examined here, the contribution of PEN to total inequality is the second largest amongst the 6 components examined.

Table 6. Brazil, Northeast Region, 1999. Division of per capita household income into 6 components: average value, share in total income and decomposition of the squared coefficient of variation $(Q)$ and of Theil's T $(T)$.

\begin{tabular}{lrlrrrr}
\hline \hline Component & $\mu(\mathrm{R} \$)$ & $\varphi$ & \multicolumn{1}{c}{$C_{Q}$} & \multicolumn{1}{c}{$\%$} & \multicolumn{1}{c}{$C_{T}$} & \multicolumn{1}{c}{$\%$} \\
\hline CSM & 17.2 & 0.122 & 6.568 & 18.2 & 1.408 & 21.5 \\
EMP & 44.7 & 0.316 & 2.864 & 20.7 & 0.497 & 19.7 \\
SLF & 28.8 & 0.204 & 1.863 & 8.7 & 0.240 & 6.1 \\
YER & 15.5 & 0.110 & 10.736 & 26.9 & 1.939 & 26.6 \\
PEN & 30.2 & 0.214 & 4.375 & 21.4 & 0.833 & 22.3 \\
RDI & 4.9 & 0.035 & 5.197 & 4.2 & 0.857 & 3.8 \\
\hline Total & 141.2 & 1.000 & 4.378 & 100.0 & 0.798 & 100.0 \\
\hline
\end{tabular}

Table 7. Brazil, Northeast Region, 1999. Division of per capita household income into 6 components: decomposition of the Gini, Mehran and Piesch indices.

\begin{tabular}{lcrrrrr}
\hline \hline Component & \multicolumn{1}{c}{$C_{G}$} & $\%$ & $C_{M}$ & $\%$ & \multicolumn{1}{c}{$C_{P}$} & $\%$ \\
\hline CSM & 0.819 & 16.5 & 0.924 & 15.6 & 0.766 & 17.1 \\
EMP & 0.516 & 27.0 & 0.646 & 28.3 & 0.450 & 26.2 \\
SLF & 0.429 & 14.5 & 0.552 & 15.6 & 0.368 & 13.8 \\
YER & 0.896 & 16.3 & 0.961 & 14.6 & 0.864 & 17.4 \\
PEN & 0.630 & 22.3 & 0.769 & 22.7 & 0.561 & 22.0 \\
RDI & 0.583 & 3.4 & 0.669 & 3.2 & 0.540 & 3.5 \\
\hline Total & 0.604 & 100.0 & 0.722 & 100.0 & 0.544 & 100.0 \\
\hline
\end{tabular}

It is interesting to compare the metropolitan regions of Rio de Janeiro and of São Paulo, as they present remarkable differences in 
the contribution of the analyzed components. Results of the decomposition for the 5 inequality measures are presented in Tables 8 to 11.

In the metropolitan region of Rio de Janeiro the share of pensions (PEN) in total income reaches $25.5 \%$ and its contribution to total inequality is the largest of all six components in the decomposition of Theil's $T$ and of the Piesch index. For the Gini and Mehran indices the largest contribution to inequality derives from the earnings of employees, but the contribution of pensions is just slightly lower.

In the metropolitan region of São Paulo the share of pensions is $13.1 \%$, a little more than half of the corresponding value in the metropolitan region of Rio de Janeiro. In São Paulo the contribution of PEN to total inequality is always in the $4^{\text {th }}$ place, below the contribution of the earnings of employees (EMP), self-employed workers (SLF) and employers (YER). For indices $G, M$ and $P$ the largest contribution derives from EMP and for measures $Q$ and $T$, the highest contribution comes from employers (YER).

Table 8. Brazil, Metropolitan Region of Rio de Janeiro, 1999. Division of per capita household income into 6 components: average value, share in total income and decomposition of the squared coefficient of variation $(Q)$ and of Theil's $\mathrm{T}(T)$.

\begin{tabular}{lrlrrrr}
\hline \hline Component & $\mu(\mathrm{R} \$)$ & $\varphi$ & \multicolumn{1}{c}{$C_{Q}$} & $\%$ & \multicolumn{1}{c}{$C_{T}$} & $\%$ \\
\hline CSM & 42.1 & 0.110 & 1.721 & 6.6 & 0.665 & 11.8 \\
EMP & 143.4 & 0.375 & 1.887 & 24.5 & 0.339 & 20.5 \\
SLF & 60.1 & 0.157 & 2.359 & 12.8 & 0.466 & 11.8 \\
YER & 30.8 & 0.080 & 10.662 & 29.7 & 1.628 & 21.1 \\
PEN & 97.6 & 0.255 & 2.618 & 23.1 & 0.755 & 31.1 \\
RDI & 8.3 & 0.022 & 4.284 & 3.2 & 1.067 & 3.7 \\
\hline Total & 382.3 & 1.000 & 2.888 & 100.0 & 0.620 & 100.0 \\
\hline
\end{tabular}


Decomposition of Mehran and Piesch inequality measures by factor components

Table 9. Brazil, Metropolitan Region of Rio de Janeiro, 1999. Division of per capita household income into 6 components: decomposition of the Gini, Mehran and Piesch indices.

\begin{tabular}{lcrrrrr}
\hline \hline Component & $C_{G}$ & $\%$ & $C_{M}$ & $\%$ & \multicolumn{1}{c}{$C_{P}$} & $\%$ \\
\hline CSM & 0.655 & 13.0 & 0.813 & 13.2 & 0.575 & 12.9 \\
EMP & 0.434 & 29.4 & 0.555 & 30.7 & 0.373 & 28.6 \\
SLF & 0.485 & 13.8 & 0.613 & 14.2 & 0.421 & 13.5 \\
YER & 0.841 & 12.2 & 0.939 & 11.1 & 0.792 & 13.0 \\
PEN & 0.625 & 28.9 & 0.754 & 28.4 & 0.560 & 29.2 \\
RDI & 0.663 & 2.6 & 0.727 & 2.3 & 0.631 & 2.8 \\
\hline Total & 0.553 & 100.0 & 0.678 & 100.0 & 0.490 & 100.0 \\
\hline
\end{tabular}

Table 10. Brazil, Metropolitan Region of São Paulo, 1999. Division of per capita household income into 6 components: average value, share in total income and decomposition of the squared coefficient of variation $(Q)$ and of Theil's $\mathrm{T}(T)$.

\begin{tabular}{lrllrrr}
\hline \hline Component & $\mu(\overline{\mathrm{R} \$})$ & $\varphi$ & \multicolumn{1}{c}{$C_{Q}$} & \multicolumn{1}{c}{$\%$} & \multicolumn{1}{c}{$C_{T}$} & \multicolumn{1}{c}{$\%$} \\
\hline CSM & 25.5 & 0.063 & 2.087 & 5.8 & 0.737 & 7.8 \\
EMP & 193.8 & 0.476 & 1.353 & 28.7 & 0.333 & 26.7 \\
SLF & 68.3 & 0.168 & 1.955 & 14.6 & 0.562 & 15.8 \\
YER & 47.5 & 0.117 & 6.035 & 31.4 & 1.581 & 31.0 \\
PEN & 53.4 & 0.131 & 1.774 & 10.4 & 0.443 & 9.8 \\
RDI & 18.4 & 0.045 & 4.501 & 9.1 & 1.174 & 8.9 \\
\hline Total & 406.9 & 1.000 & 2.245 & 100.0 & 0.595 & 100.0 \\
\hline
\end{tabular}


Table 11. Brazil, Metropolitan Region of São Paulo, 1999. Division of per capita household income into 6 components: decomposition of the Gini, Mehran and Piesch indices.

\begin{tabular}{lcrrrrr}
\hline \hline Component & $C_{G}$ & \multicolumn{1}{c}{$\%$} & \multicolumn{1}{c}{$C_{M}$} & \multicolumn{1}{c}{$\%$} & \multicolumn{1}{c}{$C_{P}$} & \multicolumn{1}{c}{$\%$} \\
\hline CSM & 0.668 & 7.6 & 0.829 & 7.6 & 0.587 & 7.6 \\
EMP & 0.456 & 39.2 & 0.598 & 41.4 & 0.386 & 37.7 \\
SLF & 0.553 & 16.7 & 0.690 & 16.8 & 0.485 & 16.7 \\
YER & 0.880 & 18.5 & 0.959 & 16.3 & 0.841 & 20.1 \\
PEN & 0.509 & 12.0 & 0.663 & 12.6 & 0.433 & 11.6 \\
RDI & 0.728 & 6.0 & 0.816 & 5.4 & 0.684 & 6.4 \\
\hline Total & 0.555 & 100.0 & 0.689 & 100.0 & 0.488 & 100.0 \\
\hline
\end{tabular}

Once again, one should keep in mind the limitations of the data on incomes obtained through the PNAD. It is estimated that, on average, declared income is around $60 \%$ of its true value. However, the degree of understatement can vary considerably according to the type of income. It is very likely that understatement is lower in case of wage earners, particularly regular civil servants. Pensions are likely to be less understated than the income of employers or self-employed. The proportion of understatement is probably even higher for rents, interest and dividends. Thus, the analysis presented above could be overestimating the contribution of the salaries of civil servants and of pensions to overall inequality in the distribution of income in Brazil. At any rate, the results we obtained are relevant. The same types of data, with all their limitations, are used to show that Brazil is amongst the countries with the highest degree of income inequality. 
Decomposition of Mehran and Piesch inequality measures by factor components

\section{Concluding remarks.}

The decomposition of the Gini index according to components of total income can easily be extended to the Mehran and Piesch indices. The interpretation of the decomposition of these three inequality measures is made easy because of its direct relationship with the position of the concentration curves. The joint use of these three indices may be useful for detecting whether differences in the decomposition of inequality in two distributions are more linked to changes in the central part of the distribution (Gini index), in the upper end of the distribution (Piesch index) or in the lower end of the distribution (Mehran index).

It is true, as noted by Shorrocks (1982), that the choice of the method of decomposition is to a large extent arbitrary. However, we obtained rather coherent results as we used five inequality measures (including the squared coefficient of variation and Theil's T) to analyze the decomposition of inequality in the distribution of per capita household incomes in Brazil according to six components of income. When significant numerical differences arise, they can be explained by taking into account the difference in the properties of the various inequality measures. Thus, the decomposition of the squared coeffcient of variation, a measure particularly sensitive to changes in the upper end of the distribution, shows that the largest contribution to inequality comes from the earnings of employers ( Table 4). On the other hand, the Gini index indicates that the largest contribution comes from the earnings of private sector employees (Table 5). And there are also cases of "unanimity": all indices show that the contribution of pensions to inequality is somewhat higher than its share in total income, which is $17.8 \%$.

Submitted in March 2003. Revised in March 2004. 


\section{References}

Hoffmann, R. 1998. Distribuição de renda: Medidas de desigualdade e pobreza. São Paulo, Editora da Universidade de São Paulo.

Hoffmann, R. 2003. "Inequality in Brazil : The contribution of pensions". Revista Brasileira de Economia, 57 (4): 755-733, oct.-dec./2003.

IBGE 2000. Pesquisa Nacional por Amostra de Domicílios 1999, Brasil. Vol. 21.

Kakwani , N. C. 1980. Income inequality and poverty: Methods of estimation and policy applications. A World Bank research publication, Oxford University Press.

Lambert, P. 1989. The distribution and redistribution of income: $A$ mathematical analysis. Basil Blackwell.

Nygard, F. \& A. Sandstrom 1981. Measuring income inequality. Stockholm, Almqvist and Wiksell International.

Pyatt, G.; C. Chen \& J. Fei 1980. "The distribution of income by factor components". Quarterly Journal of Economics, 95 (3): 451-473, Nov./1980.

Shorrocks, A. F. 1982. "Inequality decomposition by factor components". Econometrica, 50 (1):193-211, January/1982.

Shorrocks, A. F. 1983. "The impact of income components on the distribution of family incomes". Quarterly Journal of Economics, 98 (2): 311-326, May 1983.

Yitzhaki, S. 1983. "On an extension of the Gini inequality index". International Economic Review, 24 (3):617-628, Oct.1983. 



\section{Subscription Form}

To become a subscriber to The Brazilian Name

Review of Econometrics you should fill out

this form and send it to:

Institution

The Brazilian Review of Econometrics - Address

A/C: Angela Maria Bevilacqua

Praia de Botafogo, $190-10^{\circ}$ andar sala 1032

22253-900 Botafogo, Rio de Janeiro, RJ., State Brasil

Tel. (5521) 2551-4658

Postal Code

Fax (5521) 2552-4898

sbe@fgv.br - http: //www.sbe.org.br

Country

Subscriptions

Telephone

US $\$ 100 / R \$ 150,00$

Fax

Institutions and new subscribers

US\$ 50 / R $\$ 75,00$

Renewals for individual subscribers

E-Mail

Year of Subscription

US\$25/R \$ 37,50 Students

Amount in US\$ ou R\$ 


\section{Methods of Payment}

\section{Checks}

Please send a check with the value of your subscription payable to Sociedade Brasileira de Econometria which can be drawn in a Brazilian bank to the SBE office..

After we receive your check we will send you a receipt, as well as the issues of the Review that correspond to your subscription.

Checks and subscription form should be sent to:

SBE The Brazilian Review of Econometrics

A/C Angela Maria Bevilacqua

Praia de Botafogo, $190-10^{\circ}$ Andar - Sala 1032

22253-900 - Botafogo - Rio de Janeiro, RJ., Brasil

Tel. (5521) 2551-4658 - Fax (5521) 2552-4898

sbe@fgv.br - http: //www.sbe.org.br

\section{Bank Deposit}

A bank deposit must be made in the society's account at Banco do Brasil.

Please send us a fax (5521) 25524898 with a copy of your deposit slip attached to your subscription form. The fax is your proof of subscription.

Account Information

Banco do Brasil - Rio de Janeiro - RJ Brasil

Agência Botafogo

Número 0287-9

Account 112.842-6 


\section{Payment with a Credit Card}

Credit card Number

Expiration Date

Amount

Name of the Card

Signature

Date

We accept Diners, Master Card e Credicard

Send subscription form to

SBE The Brazilian Review of Econometrics - Revista de Econometria A/C: Angela Maria Bevilacqua

Praia de Botafogo, $190-10^{\circ}$ andar - sala 1032

22253-900 Botafogo, Rio de Janeiro, RJ., Brasil

Tel. (5521) 2551-4658

Fax (5521) 2552-4898

sbe@fgv.br - http: //www.sbe.org.br 



\title{
Submission of Manuscripts to the Brazilian Review of Econometrics
}

1. Four copies of the original manuscript should be sent to:

\author{
Angela Maria Bevilacqua \\ Editorial Assistant, Brazilian Review of Econometrics \\ EPGE - Fundação Getulio Vargas \\ Praia de Botafogo, 190 - 10o. Andar \\ Rio de Janeiro, RJ 22250-900 Brazil.
}

Two copies of the manuscript should not have the author's name indicated o revealed in any manner. The manuscripts must be accompanied by a submission letter and be written in English or Portuguese. Submission of a paper is helc to imply its contents represent original and unpublished work, and that it ha: not been submitted elsewhere. Manuscripts are always refereed and may $b_{1}$ rejected, returned for specified revisions or accepted.

2. Manuscripts should have an opening page containing the title, the author': name(s), address(es), e-mail and affiliation. It should also contain a set of $K e_{i}$ Words and Phrases, a primary and secondary Journal of Economic Literatur, classification for the manuscript and an Abstract in English of at most $15 \mathrm{C}$ words.

3. Manuscripts should be typed with double line spacing on standard size paper: preferably $8.5 \times 11$ inches, in a font size of 10 or $12 \mathrm{cpi}$. The typing area of al] pages should be no more than $5.5 \times 8.5$ inches $(14 \times 21.6 \mathrm{~cm})$.

4. Tables should be typed as part of the text, but in such a way as to avoid confusion with text, extra space should be left above and below the table. Tables, including title, legend, label or number, should fit within the standard typing area and should not run over to the next page.

5. Graphs and other numbered figures should be separate from the text, sized to fit within the width and height of the typed pages and be ready for printing.

6. References should be indicated in the text by the author's name and the year of publication in parentheses. All references should then be collected in alphabetical order at the end of the manuscript.

7. Any acknowledgements, including citations to supporting grants and contracts, should be typed as text and placed before the references at the end of the manuscript. 


\title{
Submissão de Manuscritos para a Brazilian Review of Econometrics
}

1. Quatro cópias do manuscrito original devem ser enviadas para:

\author{
Angela Maria Bevilacqua \\ Editorial Assistant, Brazilian Review of Econometrics \\ EPGE - Fundação Getulio Vargas \\ Praia de Botafogo, 190 - 10o. Andar \\ Rio de Janeiro, RJ 22250-900 Brazil.
}

Em duas cópias do manuscrito não deverá constar o nome do autor indicado ou revelado de nenhuma maneira. Os manuscritos deverão ser escritos em inglês ou português e acompanhados por uma carta de submissão. A submissão de um manuscrito implica que seu conteúdo é original, não publicado e que não está submetido para publicação a nenhum outro periódico. Os manuscritos são sempre julgados por pareceristas e podem ser rejeitados, devolvidos para revisōes específicas ou aceitos.

2. Os manuscritos devem ter uma página de abertura contendo o título, o(s) nome(s) do(s) autor(es), endereço(s), e-mail e afiliação. Também deverá conter uma série de Palavras-Chave e Frases, uma classificacão primária e secundária para o manuscrito de acordo com o sistema do Journal of Economic Literature e um Abstract em inglês de no máximo 150 palavras.

3. Os manuscritos devem ser digitados com espaço duplo, em papel tamanho padrão, preferencialmente $8.5 \times 11$ polegadas, com um tamanho de fonte 10 ou $12 \mathrm{cpi}$. A área total da página a ser digitada não deverá ser maior do que $5.5 \times 8.5$ polegadas $(14 \times 21.6 \mathrm{~cm})$.

4. As Tabelas devem ser digitadas como parte do texto, mas de maneira a evitar confusão com o mesmo, espaço extra deve ser deixado acima e abaixo da tabela. Tabelas, incluindo título, legenda, selo ou número, deverão ajustar-se à área de digitação e não deverão passar para a próxima página.

5. Gráficos e outras figuras numeradas devem ser separados do texto, com um tamanho que se ajusta à largura e altura das páginas digitadas para impressão.

6. As referências devem ser indicadas no texto pelo nome do autor e o ano da publicacão entre parênteses. Todas as referências deverão ser grupadas em ordem alfabética no final do manuscrito.

7. Quaisquer agradecimentos, incluindo citaçoes, permissōes de apoio e contratos, devem ser digitados no texto e colocados antes das referências no final do manuscrito. 